\title{
Effect of acetoacetate administration on urinary and tissue vitamin $B_{6}$ in rats
}

\author{
By M. C. NATH AND N. V. SHASTRI \\ University Department of Biochemistry, Nagpur, India \\ (Received 31 Fanuary I969-Accepted I4 April I969)
}

\begin{abstract}
I. Experiments were undertaken to study the effect of daily intraperitoneal injection of acetoacetate for 90 days on vitamin $B_{6}$ status in male albino rats. The initial dose of acetoacetate was $50 \mathrm{mg}$ per $\mathrm{kg}$ body-weight, which was increased by $50 \mathrm{mg}$ per $\mathrm{kg}$ body-weight every I 5 days.

2. Urinary excretion of vitamin $B_{6}$ was found to decrease after 30 days in acetoacetatetreated rats. After 75 days urinary values of vitamin $B_{6}$ were considerably lower in such rats than in the corresponding control rats.

3. When acetoacetate injections were stopped after 90 days and the rats were fed L-tryptophan (roomg per rat), they were found to excrete significantly greater amounts of urinary kynurenine, hydroxykynurenine and xanthurenic acid than the corresponding controls.

4. Blood and liver vitamin $B_{6}$ levels were found to be lower in rats treated with acetoacetate for 90 days than in the untreated rats.
\end{abstract}

Prolonged administration of acetoacetate has been previously reported from this laboratory to result in a decrease in urinary and tissue levels of nicotinic acid in rabbits (Nath \& Chakrabarti, I953) and rats (Shastri, Nayudu \& Nath, 1967). Shastri et al. (1967) further observed that conversion of tryptophan into nicotinic acid was affected in rats receiving single and multiple injections of acetoacetate. An intraperitoneal injection of acetoacetate was found to result in excretion of abnormally large amounts of urinary kynurenine, hydroxykynurenine and xanthurenic acid in rats fed tryptophan (Nath \& Shastri, 1969).

Ketone bodies have been found in large quantities after feeding high-fat diets (Khanade \& Nath, I960) and have been thought to be responsible for the deleterious effects of such diets. Kotake (I955) observed pyridoxine deficiency and an increase in urinary and xanthurenic acid excretion in rats given high-fat diets and tryptophan, and also an increase in the ketone bodies in urine of pyridoxine-deficient rats. In the light of these observations, it was thought worth while to study the effect of continued administration of acetoaceate on the vitamin $B_{6}$ status of rats.

\section{EXPERIMENTAL}

Male albino rats $(40-5 \circ \mathrm{g})$ were divided into two equal groups of equal mean bodyweight and were fed on a stock laboratory diet consisting of wheat flour $60 \%$, groundnut oil $9 \%$, shark-liver oil I $\%$, casein $20 \%$, Hawk-Oser salt mixture $5 \%$ and yeast $5 \%$. The food and water were given ad lib.

The rats of the second group were injected intraperitoneally with sodium acetoacetate daily; the initial dose was $50 \mathrm{mg} / \mathrm{kg}$ body-weight and this was increased by $50 \mathrm{mg} / \mathrm{kg}$ every ${ }_{5}$ days. Urinary vitamin $\mathrm{B}_{6}$ was determined in both groups every 
I $5^{\text {th }}$ day of the experiment. After 90 days the injections were stopped and half the animals in each group were placed in metabolic cages, two in a cage, and their urine was collected during the following $24 \mathrm{~h}$.

Each rat was then given Ioo $\mathrm{mg}$ of L-tryptophan by stomach tube and urine was again collected during the following $24 \mathrm{~h}$ and analysed for various tryptophan metabolites. The remaining rats from each group were stunned and decapitated, and the total vitamin $\mathrm{B}_{6}$ levels of their blood and liver were estimated.

Urine samples were collected under toluene and stored in the deep-freeze until analysed. The analyses were performed within 2 days of collection. Total vitamin $B_{6}$ was estimated by the yeast microbiological method described by Oser (1965). Acetylkynurenine, anthranilic acid and kynurenine were determined by the methods of Brown \& Price (1956). Hydroxykynurenine was estimated by the procedure of Brown (1957) and kynurenic and xanthurenic acid by that of Satoh \& Price (1958).

\section{RESULTS}

Table $I$ indicates that, for 30 days, there was no significant difference in urinary vitamin $B_{6}$ levels between rats given acetoacetate and controls, and the levels decreased gradually in acetoacetate-treated rats. After 90 days urinary levels of vitamin $B_{6}$ in acetoacetate-treated rats were considerably lower than those in controls.

Table I. Effect of daily intraperitoneal injections of acetoacetate on urinary excretion of vitamin $B_{6}$ in rats

(Mean values and standard deviations for sixteen rats; eight determinations on the pooled urine of two rats each)

Urinary excretion of vitamin $B_{6}(\mu \mathrm{g} /$ rat day) on day:

\begin{tabular}{|c|c|c|c|c|c|c|c|}
\hline Group & I & I5 & 30 & 45 & 60 & 75 & 90 \\
\hline Controls & $\begin{array}{r}7 \cdot 3 \\
\pm 0.8\end{array}$ & $\begin{array}{r}12.5 \\
\pm 13\end{array}$ & $\begin{array}{r}13.0 \\
\pm 27\end{array}$ & $\begin{array}{r}16 \cdot I \\
\pm 2 \cdot I\end{array}$ & $\begin{array}{r}I_{5} \cdot 8 \\
\pm I \cdot I\end{array}$ & $\begin{array}{r}18 \cdot 5 \\
\pm 3 \cdot 1\end{array}$ & $\begin{array}{r}19.8 \\
\pm 2.5\end{array}$ \\
\hline Treated & $\begin{array}{r}8 \cdot 4 \\
\pm 1 \cdot 2\end{array}$ & $\begin{array}{r}14.5 \\
\pm 1.9\end{array}$ & $\begin{array}{r}12.3 \\
\pm 2.0\end{array}$ & $\begin{array}{l}10.8 * \\
\pm \mathrm{I} \cdot 8\end{array}$ & $\begin{array}{l}9.0^{*} \\
\pm 1.7\end{array}$ & $\begin{array}{l}\text { I I } \cdot 0^{* * *} \\
\pm \text { I.0 }\end{array}$ & $\begin{array}{l}9 \cdot 4^{* * *} \\
\pm 1 \cdot 3\end{array}$ \\
\hline
\end{tabular}

Table 2. Urinary excretion of tryptophan metabolites ( $\mu$ moles per rat per day) in normal rats and rats treated with a daily injection of acetoacetate for 90 days, before and after administration of $100 \mathrm{mg}$ L-tryptophan per rat by stomach tube

(Mean values and standard deviations for eight rats; four determinations on the pooled urine of two rats each)

\begin{tabular}{|c|c|c|c|c|}
\hline \multirow[b]{2}{*}{ Metabolite } & \multicolumn{2}{|c|}{ Normal rats } & \multicolumn{2}{|c|}{ Treated rats } \\
\hline & Before & After & Before & After \\
\hline Acetylkynurenine & $0.01 \pm 0.01$ & $3 \cdot 4 \pm \mathrm{r} \cdot 8$ & $0.01 \pm 0.009$ & $4 \cdot 9 \pm I \cdot 4$ \\
\hline Athranilic acid & $2 \cdot 2 \pm I \cdot 4$ & I I.7 $72 \cdot 5$ & $2 \cdot 9 \pm 1 \cdot 5$ & $10.0 \pm 3.2$ \\
\hline Kynurenine & $0.2 \pm 0.04$ & $4 \cdot 6 \pm 1 \cdot 2$ & $0.1 \pm 0.06$ & $7 \cdot 8 \pm 2 \cdot 7^{* *}$ \\
\hline Hydroxykynurenine & $0.4 \pm 0.1$ & $7 \cdot 2 \pm 0.7$ & $0.3 \pm 0.1$ & $20 \cdot 7 \pm 4 \cdot 1 * *$ \\
\hline Kynurenic acid & $0.4 \pm 0.2$ & $34 \cdot 0 \pm 7 \cdot 5$ & $0.2 \pm 0.1$ & $32 \cdot 5 \pm 9 \cdot 2$ \\
\hline Xanthurenic acid & $0.5 \pm 0.2$ & $7 \cdot 4 \pm 1 \cdot 9$ & $0.3 \pm 0.2$ & $27 \cdot 0 \pm 6 \cdot 4^{* *}$ \\
\hline
\end{tabular}


When, after 90 days, the acetoacetate injections were stopped and rats of both groups were given tryptophan orally (Table 2 ), the acetoacetate-treated rats were found to excrete considerably greater amounts of kynurenine, hydroxykynurenine and xanthurenic acid in their urine than control rats. Liver and blood vitamin $B_{6}$ levels (Table 3 ) were found to be lower in acetoacetate-treated rats than in control rats.

\section{Table 3. Effect of a daily injection of acetoacetate for 90 days on tissue vitamin $\mathrm{B}_{6}$ levels in rats}

\begin{tabular}{|c|c|c|c|c|}
\hline \multicolumn{5}{|c|}{ (Mean values and standard deviations) } \\
\hline & & & \multicolumn{2}{|c|}{ Vitamin $\mathrm{B}_{6}$ content } \\
\hline Group & $\begin{array}{l}\text { No. of } \\
\text { animals }\end{array}$ & $\begin{array}{c}\text { Mean wt at } \\
\text { death }(g)\end{array}$ & $\begin{array}{l}\text { Liver } \\
(\mu \mathrm{g} / \mathrm{g})\end{array}$ & $\begin{array}{c}\text { Blood } \\
(\mathrm{mg} / 100 \mathrm{ml})\end{array}$ \\
\hline $\begin{array}{l}\text { Normal } \\
\text { Treated }\end{array}$ & $\begin{array}{l}8 \\
7\end{array}$ & $237 \pm 18$ & $\begin{array}{l}25.2 \pm 3.0 \\
56.4+3.8 *\end{array}$ & $34.4 \pm 5.3$ \\
\hline 1 reated & 7 & $184 \pm 13$ & $10^{\circ} 4 \pm 3.8$ & $25^{\circ} \pm 4^{\circ} I^{\prime \prime}$ \\
\hline
\end{tabular}

\section{DISCUSSION}

Results of this study showed that prolonged administration of acetoacetate caused depletion of vitamin $B_{6}$ in urine and tissues of rats. Significant depletion of urinary vitamin $B_{6}$ was observed after $3 \circ$ days. Table 3 indicated that the injected animals did not grow as well as controls and therefore some of the differences between the two groups in Table I may have been due to the differences in body-weight. It appears possible that depletion of vitamin $\mathrm{B}_{6}$, observed in acetoacetate-injected rats, may be a contributing factor in the disturbed biosynthesis of nicotinic acid observed in such animals (Shastri et al. 1967), since normal biosynthesis of nicotinic acid is known to be affected in pyridoxine deficiency (Henderson, Koski \& D’Angeli, 1955).

The authors wish to thank the Council of Scientific and Industrial Research, India for financial assistance.

\section{REFERENCES}

Brown, R. R. (1957). \%. biol. Chem. 227, 649.

Brown, R. R. \& Price, J. M. (1956). F. biol. Chem. 219, 985.

Henderson, L. M., Koski, R. E. \& D'Angeli, F. (1955). F. biol. Chem. 215, 369.

Khanade, J. N. \& Nath, M. C. (1960). Proc. Soc. exp. Biol. Med. 105, 566.

Kotake, Y. (1955). F. Vitam. I, 73.

Nath, M. C. \& Chakrabarti, C. H. (1953). Proc. Soc. exp. Biol. Med. 82, 5.

Nath, M. C. \& Shastri, N. V. (1969). Br. F. Nutr. 23, 153.

Oser, B. L. (1965). Hawks Physiological Chemistry, 14th ed., p. 647. New York: McGraw-Hill Book Company.

Satoh, K. \& Price, J. M. (1958), F. biol. Chem. 230, 78r.

Shastri, N. V., Nayudu, S. G. \& Nath, M. C. (1967). F. Vitam. 13, 47. 